\title{
MINERAL RESOURCE POTENTIAL OF THE ROADLESS AREAS AND THE SANTA LUCIA WILDERNESS IN THE LOS PADRES NATIONAL FOREST, $\checkmark$ SOUTHWESTERN CALTFORNA
}

\section{SUMMARY REPORT}

\author{
By
}

\author{
Virgil A. Frizzell, Jr., and David B. Smith \\ U.S. Geological Survey
}

and

Lucia Kuizon and William N. Hale U.S. Bureau of Mines

\section{STUDIES RELATED TO WILDERNESS}

Under the provisions of the Wilderness Act (Public Law 88-577, September 3, 1964) and the Joint Conference Report on Senate Bill 4, 88th Congress, the U.S. Geological Survey and the U.S. Bureau of Mines have been conducting mineral surveys of wilderness and primitive areas. Areas officially designated as "wilderness," "wild," or "canoe" when the act was passed were incorporated into the National Wilderness Preservation System, and some of them are presently being studied. The act proviced that areas under consideration for wilderness designation should be studied for suitability for incorporation into the Wilderness System. The mineral surveys constitute one aspect of the suitability studies. The act directs that the results of such surveys are to be made available to the public and be submitted to the President and the Congress. This report discusses the results of a mineral survey of the Santa Lucia Wilderness and 22 roadless area that consist of the Sespe-Frazier, Garcia Mountain, Black Mountain, La Panza, Machesna Mountain, Los Machos Hills, Big Rocks, Stanley Mountain, Miranda Pine, Horseshoe Sprin rs, Tepusquet Peak, La Brea, Spoor Canyon, Fox Mountain, Diablo, Matilija, Dry Lakes, Sawmill-Badlands, Cuyama, Antimony, Quatal and Little Pine Roadless Areas. All the roadless areas occur in the Los Padres National Forest, Kern, Los Angeles, San Luis Obispo, Santa Barbara, and Ventura Counties, California. The Santa Lucia Wilderness was established by Public Law 95-237 in 1978. The twenty-two roadless areas were classified as further-planning areas during the Second Roadless Area Review and Evaluation (RARE II) by the U.S. Forest Service, January 1979.

\section{SUMMARY}

The study area in the Los Padres National Forest contains mines, prospects, and occurrences that contain identified resources of antimony, barite, bentonitic clay, building stone (sandstone and marble), copper, gold, gypsum, petroleum, phosphate rock, silver, uranium, and zinc, but geologic and geochemical investigations generally indicate little potential for the presence of these mineral commodities at other localities within the study area. The few areas with potential for additional mineral resources are associated with those containing known resources or are present in similar geologic settings. Anomalies identified from nur geochemical study are related to localities previously known for mineralization; no new areas of mineral resource potential were delineated as a result of the geochemical study.

Several roadless areas contain resources or reserves (see table 1): the Sespe-Frazier Roadless Area (RA) contains bentonitic clay, lode gold, gypsum, petroleum, and phosphate rock; the Black Mountain RA contains uranium; the Horseshoe Spring RA contains building stone (sandstone); the La Brea RA contains barite, copper, and zinc; the Fox Mountain RA contains phosphate rock; the Cuyama RA contains gypsum; the Antimony RA contains antimony, building stone (marble), gold, and silver; and the Quatal RA contains bentonitic clay.

Phosphate-rock reserves in the Sespe-Frazier RA are minable under 1982 conditions. Bentonitic clay in the Sespe-Frazier RA and sandstone in the Horseshoe Spring RA are marginal reserves because reserves outside the study area meet current marl demands. Marble and other sandstone deposits in the study area are subeconomic resources because of high transportation corts and occurrences outside the study area which supply current needs. The deposits of antimony, barite, copper, gold, gypsum, silv $\gg r$, uranium, and zine contain either marginal reserves or subeconomic resources because of combinations of low commodity pric:s, generally low grade and tonnage, high mining and benefication costs, and poor access.

Petroleum will probably continue to be found in and around the Sespe oil fields and may be present below thrust faults in two parts of the study area in the Sespe-Frazier RA.

Low to moderate potential exists for the presence of undiscovered antimony resources in part of the Antimony RA. Low to moderate potential exists for the presence of undiscovered barite resources throughout the study area. Low to moderate potential exists for the presence of additional low-grade lode gold resources in parts of the Sespe-Frazier and Antimony RAs. Low to moderate potential exists for the presence of low-grade mercury resources in part of the Stanley Mountain RA. A low to modirsate potential exists for the presence of undiscovered oil and gas in Miocene and younger rock throughout the study area, and a moderate potential exists for the presence of undiscovered oil and gas at two localities in the Sespe-Frazier RA. A low to modirrate potential exists for the presence of low-grade uranium resources at depth in parts of the Black Mountain RA.

\section{INTRODUCTION}

This report summarizes the results of a mineral survey in the Santa Lucia Wilderness and 22 roadless areas, consisting of the Sespe-Frazier, Garcia Mountain, Black Mountain, La Panza, Machesna Mountain, Los Machos Hills, Big Rocks, Stanley Mountain, Miranda Pine, Horseshoe Springs, Tepusquet Peak, La Brea, Spoor Canyon, Fox Mountain, Diablo, Matilija, Dry Lakes, Sawmill-Badlands, Cuyama,
Antimony, Quatal and Little Pine Roadless Areas. These roadless areas all occur in the Los Padres National Forest, Kern, Los Angeles, San Luis Obispo, Santa Barbara, End Ventura Counties, California (fig. 1). For purposes of this report the individual areas are referred to collectively as the study area. The roadless areas individually range from abnut 2 to $523 \mathrm{mi}^{2}$ (fig. 1) and the study area totals some $1336 \mathrm{mi}$. The multidisciplinary study was conducted jointly by the U.S. Geological Survey and the U.S. Bureau of Mines in 
1980 through 1983. The Bureau of Mines conducted investigations that included field mapping, sampling of mines, prospects, and mineralized areas, mining-claim searches, and literature reviews. The Geological Survey studied mineralized areas and searched for previously unknown mineral occurrences using geologic, geophysical, and geochemical techniques.

\section{Location and accessibility}

The study area is in the Los Padres National Forest in the southern part of the Coast Ranges and western part of the Transverse Ranges of California. It forms an elongate curved area between U.S. Highway 101 on the west and Interstate 5 on the east. California State Highways 33,58 , and 166 provide paved approaches to numerous paved and unpaved roads that generally allow access to within a quarter mile of the borders of the various roadless areas. Trails provide access into many parts of most roadless areas.

\section{Topography and vegetation}

The study area is mostly characterized by steep-walled canyons and sharp ridges. Mountain top altitudes vary from 2,868 $\mathrm{ft}$ at Lopez Mountain in the Santa Luca Wilderness to $\mathbf{8 , 8 3 1} \mathrm{ft}$ at Mt. Pinos in the Sawmill-Badlands Roadless Area. Although some summit ridges support forests of coniferous trees and riparian woodlands line some valley bottoms, impenetrable chaparral covers much of the vegetated portion of the study area. Mixtures of manzanita, buckbush, chamise and poison oak characterize the chaparral plant community and make off-trail traverses quite challenging and slow.

\section{Sources of data}

This report is based upon data derived from various disciplines involved in the investigation of the study area, which are described in reports on the geology (Frizzell and Vedder, 1985), inorganic geochemistry (Smith and others, 1985; Adrian and others, 1984), organic geochemistry (Frizzell and Claypool, 1983; Frederickson, 1985), geophysics (Griscom, 1985a, b; Dickinson, 1982; Dickinson and others, 1982), and investigations of mines and prospects (Avery, 1981; Barnes, 1981; Benham, 1983; Benham and MeCulloch, 1981; Capstick and Hyndman, 1982a, b; Denton, 1982; Gabby, 1981; Hale and others, 1983; Horn, 1983; Kuizon, 1981, 1982, 1983 a, b, c, d; Lambeth, 1982; Lipton, 1981; Longwill, 1982; McCulloch and Neuman, 1982; Sabine and Esparza, 1981; and White, 1982a, b), which are summarized by U.S. Bureau of Mines (1985). Preliminary conclusions based upon all of these data were presented in Frizzell and Hale (1983) and Frizzel and Kuizon (1983a, b).

Other mineral resource evaluations have been carried out for different parts of the Los Padres. National Forest. These include a study of mineral resources in the San Rafael Primitive Area (Gower and others, 1966), the Ventana Primitive Area (Pearson and others, 1967), and additions to the Ventana Primitive Area (Seiders and others, 1983). Mineral occurrences for the Antimony RA are discussed in a county report by Troxel and Morton (1962). Weber and others (1973) describe mineral occurrences in the southern part of Ventura County.

\section{Acknowledgments}

Numerous colleagues from the U. S. Bureau of Mines (see references table 1) enhanced our understanding of mineral occurrences, including: D. W. Avery; D. J. Barnes; J. R. Benham; D. O. Capstick; D. K. Denton, Jr.; L. E. Esparza; P. N. Gabby; D. E. Graham; M. C. Horn; P. C. Hyndman; R. H. Lambeth; D. A. Lipton; W. D. Longwill; R. B. McCulloch; T. R. Newmann; C. E. Sabine; W. W. White, III; and R. A. Winters. Likewise, numerous individuals at the U. S. Geological Survey also supported various aspects of this endeavor: field, laboratory, and library assistance was provided by Lydia K. Fox, Kathleen M. Ort, Frederika C. Moser, and Theresa Swint; Cathrine R. MeMasters provided superb drafting; George Claypool, Ted Daws, B. M. Adrian, R. B. Vaughn, and
C. M. McDougal eased interpretations of organic and inorganic geochemistry; Russ Campbell, John Crowell, Tom Dibblee, Thane McCulloh, Bob Powell, Jack Vedder, and others participated in conversations that broadened our understanding of the regional geology. Very importantly, the cooperation and continuing patience of the supervisors and staff of the various districts in the Los Padres National Forest are greatly appreciated, os are the challenging discussions offered by Hollis Record, the forest geologist.

\section{GEOLOGY AND STRUCTURE}

Despite its large size, much of the study area is composed of similar rock types. Thick sequences of Mesozoic and Cenozoic sedimentary rocks underlie most of the study area (fig. 2). These sedimentary rocks overlie crystalline basement rocks composed mostly of pre-Tertiary metamorphic and igneous intrusive rocks. Many maps and articles showing or discussing the geology of the study area are cited by Frizzell and Vedder (1985).

Large areas underlain by pre-Tertiary metamorphic and intrusive rocks occur in both the extreme northeastern and northwestern parts of the study area. Included are undifferentiated metasedimentary rocks distributed as screens and pendants within the plutonic rocks. These metasedimentary rocks include layered to spotted mica schist, metasandstone, metaquartzite, amphibolite, marble and minor calcsilicate rock, and greenschist. Also included in the unit are undifferentiated Precambrian granitic gneisses, Mesozoic granitic and ophiolitic rocks, and minor Tertiary igneous rocks.

Most of the rest of the study area is underlain by highly folded, in part chaotic, pre-Neogene sedimentary rocks. They comprise a thick, heterogeneous, incomplete marine section of interbedded sandstone, siltstone, shale, conglomerate and minor marble, ranging in age from Late Jurassic to Oligocene, with local nonmarine interbeds.

Neogene (Miocene and Pliocene) marine sedimentary rocks include organic-rich siltstone and shale, interbeaded sandstone, and lesser conglomerate. These rocks formed mostly from sediments deposited in relatively restricted marine basins where the organic remains of aquatic flora and fauna living in the water column constituted a relatively important source of sediment. Neogene nonmarine rocks occur mostly in the Cuyama Badlands, Lockwood Valley, and along the eastern boundary of the study area in the Ridge Basin. These reddish rocks include interbedded arkosic sandstone, claystone, conglomerate, and bentonitic clay representing alluvial-fan, stream, and lacustrine deposits.

Several major and numerous minor faults traverse the study area and exhibit offsets ranging from a few feet to 150 mi. Some of these faults have created physio-chemical environments that locally control the presence of minerals. For example, the low-grade mercury deposits at the Deer Trail mine near the Stanley Mountain RA are in rocks fractured in response to movements on nearby faults. Faults create barriers through which fluids, such as oil and gas, cannot move; in addition, if the overriding fault block is thick enough, temperatures can be elevated within the overridden block. Faults having some thrust component include the South Cuyama and the Pine Mountain faults, and the San Cayetano thrust.

In addition to being faulted, the sedimentary rocks in the study area are generally much folded. Anticlines traditionally are important traps for oil and gas. These structural features are delineated on maps more detailed than the one presented herein (see Vedder and others, 1973; Dibblee, 1973; and numerous references in Frizzell and Vedder, 1985).

\section{GEOPHYSICAL STUDIES}

Geophysical studies included the compilation and analysis of gravity, magnetic, and radiometric data (Griscom, 1985a, b; Dickinson, 1982; Dickinson, and others, 1982). The gravity data indicate relatively thin sections of Neogene rock in the southern half of the Santa Lucia Wilderness and south of the South Cuyama oil field in the northern Fox Mountain RA. It confirms thicker amounts of Neogene sedimentary 
rocks below the San Cayetano thrust in the southern part of the Sespe-Frazier RA and also may indicate a small amount of Neogene sedimentary rocks below the Pine Mountain fault at Pine Mountain. Magnetic data reflect the presence of granitic bedrock highs and indicate ultramafic rocks, but the data do not provide information on mineral deposits in the study area.

Although the radiometric data are equivocal, rather distinct radiometric anomalies occur over claims on Superior Ridge south of the study area and in the Hartman Ranch area in the upper Sespe drainage. Uranium mineralization has occurred in the lower part of the Sespe Formation in both these areas.

\section{GEOCHEMISTRY}

Inorganic geochemistry

A reconnaissance geochemical study was undertaken in 1981 and 1982 to assist in the evaluation of the mineral resource potential of the study area (Smith and others, 1985; Adrian and others, 1984). Several sample media were used in this study. The initial reconnaissance sampling consisted of stream sediments and panned concentrates from stream sediments. Selected rock samples were also taken from some mines and prospects to determine suites of elements related to mineralization and also from geologic units to determine geoehemical background values. In addition, 16 water samples were taken from springs to determine if any mineralizing processes are operating in the ground waters of the region. During followup studies, an additional 47 rock samples were taken from areas that showed anomalous (above average for the study area) elemental concentrations in stream-sediment and/or panned-concentrate samples. In total, 451 streamsediment, 451 panned-concentrate, 95 rock, and 16 water samples were taken for the geochemical study.

Stream sediments were chosen as the primary sample medium for the inorganic geochemical study because they represent a composite of rock and soil exposed in the drainage basin upstream from the sample site. Analysis of the heavy, nonmagnetic fraction of the panned concentrates from stream sediments proved to be useful in evaluating the common ore-forming sulfide and oxide minerals as well as other nonmagnetic minerals, such as barite, zircon, sphene, apatite, rutile, and native gold.

The largest anomalies were found in heavy-mineral concentrates from the Antimony RA. High values of antimony, arsenic, tungsten, tin, and boron appear to be related to previously recognized mineralization at Antimony Peak (antimony sulfide vein), Black Bob Canyon (the Black Bob gold deposit), and Brush Mountain (uranium prospects). Smaller, more scattered, and less consistent anomalies for tungsten, molybdenum, lanthanum, and bismuth from heavy-mineral concentrates from streams draining igneous and metamorphic terrain in the Sespe-Frazier RA are believed to be spatially related to numerous known gold occurrences there.

All anomalies identified from this geochemical study seem to be related to areas previously known for mineralization. No new areas of mineral resource potential were delineated as a result of the geochemical sampling program.

\section{Organic geochemistry}

One hundred and sixty samples of siltstone and shale were collected, primarily from natural and artificial surface exposures, and analyzed for oil-source capability and thermal maturity of the kerogen. Results of the reconnaissance study are detailed in Frizzell and Claypool (1983) and summarized below.

Most samples from pre-Neogene rocks contain less than one percent organic carbon. The data indicate that most of the organic matter present in these rocks has little capacity to generate oil and that terrestrial woody humic matter, possible source of natural gas, is the likely source of the organic carbon. Neogene marine rocks, on the other hand, contain organic matter in quantities and qualities conducive to the generation of oil, as well as gas.
These conclusions corroborate, in part, resu'ts of previous studies. Howell and Claypool (1977) studied' Late Cretaceous rocks, and they concluded that those rocks have poor source and reservoir potential. Link and Smith.(1r92, p. 191-197) conclude that the mostly nonnmarine rocks in the Miocene and Pliocene Ridge Basin contain limited numb nes of potential source beds with generally immature kerogens.

In addition to problems of locating suitable source rocks, rocks suitable for reservoir purposes are diffic'llt to delineate. Data for 67 surface and subsurface samp's of sandstone and siltstone, mostly pre-Neogene in age, in $0^{-}$near the study area indicate that the rocks have very low pirmeability and porosity and, thus, have poor reservoir potential (Frizzell and Claypool, 1983).

\section{COMMODTY INVENTORY AND EVALUATION}

Numerous commodities have been mined or prosfected for within the study area. For the commodities for whirh we have data or a history of interest, this section briefl y deseribes the mining or prospecting history, the geologir setting, any production, workings, sample analyses and iden tified resources (see table 1 for occurrences). The areas that have more than a low potential for the presence of undisecvered mineral resources are noted (see fig. 3 ). Numerous additional mines, prospeets, and localities for the various commcdities are listed in the individual reports by the U.S. Bure $n$ of Mines (see references, table 1 ) as well as a companior map (U.S. Bureau of Mines, 1985).

The assignment of modifiers to the term "potent " $\mathrm{l}$ " in this and the following section involves integrating $(\varepsilon)$ the geologic setting of the commodity; (b) knowledge of the presence or absence of occurrences, mines and prospects for a given commodity in a given geologic setting; and (c) geochemical data. Given the uncertainties involved, the a rsignment of "no potential" to an area for a given commndity would be highly speculative; therefore this category is not used. "Low potential" indicates that a locality may contain dispersed mineral occurrences, which have few favorable geologic factors and which appear to have little possibility for the presence of undiscovered mineral deposits. "Mocerate potential" indicates favorable geologic factors and locelities that have a reasonable possibility for the presence of undiscovered mineral deposits.

\section{Antimony}

Antimony deposits at Antimony Peak in the Antimony RA (location 12, table 1) were rediscovered in 1853 and were patented in the late 1800 's. These deposits had apparently been previously mined by Indians and Jesuits. About 600 tons of antimony ore was produced from this property between 1882 and 1941 (Jermain and Ricker, 1949, p. 2). At Antimony Peak, stibnite and antimony oxides occur in siliceous lenses irregularly distributed along a shear zone in quartz dioritetonalite (Troxel and Morton, 1962, p. 56; Jermain and Richer, 1949). Strong antimony anomalies (and smaller anomal' is in tungsten, tin, and boron) occur in streams draining the Antimony Peak area, and rocks from the area of the peak show amomalies in antimony, arsenic, tungsten, merrury, boron, and silver, in addition to small gold values (Smit' ' and others, 1985). The patented Antimony Peak mine cortains 470,000 tons of indicated and inferred marginal reserver and subeconomic resources averaging 1.0 to 2.7 percent antimony (Kuizon, 1982, p. 4). By comparison, commercial grad? ore mined under different economic conditions elsewhere in the United States contains 5 to 10 percent antimony (Goldman, 1957, p. 35). Two areas, one near Antimony Peak and anther just east of Antimony Peak, have low to moderate potential for the presence of additional low-grade antimony resources. None of our data indicate a potential fo- the presence of undiscovered antimony resources elsewhere in the study area.

\section{Barite}

Barite occurs at the patented White Elephant mine (location 6, table 1) in the La Brea RA where 4,000 tons of 
ore were produced in 1929 and 1930. The mineral occurs as veins in brecciated Cretaceous sandstone and siltstone. About 95,000 tons of 73 percent inferred subeconomic barite resources remain on the claims (Benhan and McCulloch, 1981, p. 7). Sustained production at commercial deposits outside the study area has been from barite deposits with more than 17,000 tons of 96 percent barite (Kundert, 1957, p. 73).

Panned-concentrate samples downstream from the mine had visible barite and showed high values for barium (greater than 1 percent barium). However, this is not conclusive evidence for the presence of undiscovered barite veins, because a majority of the panned concentrates from the entire study area had barium values greater than one percent. The high barium content in the samples of stream sediments derived from sedimentary rocks and a high content of sulfate in spring waters sampled may indicate the presence of barite veins elsewhere in the study area (Smith and others, 1984), although no other occurences of vein barite have been found. Therefore, while low to moderate potential exists for the presence of undiscovered barite resources in the study area, the widespread nature of the barium anomalies makes it impossible to delineate specific localities other than the known occurrence in the La Brea RA.

\section{Bentonitic Clay}

Parts of the nonmarine Neogene Lockwood Clay of Carman (1964) locally contain rather pure bentonitic clay. The clay probably represents the altered remnants of a volcanic ash layer that became interbedded in the nonmarine deposits (Carman, 1964, p. 44). A deposit in the eastern part of Lockwood Valley, from which 13 million tons were produced between 1954 and 1980 (White, 1982b, p. 8), has 7.2 million tons of bentonitic clay reserves, of which about 4.7 million tons (location 1, table 1) occur within the SespeFrazier RA (Hale and others, 1983, p. 17, table 2, No. 13). Although the Lockwood Clay erops out locally in the SawmillBadlands RA, no resources are estimated there (Longwill, 1982 , p. 9,16 ). Bentonitic clay resources occur, however, in the Quatal RA where about 1.6 million tons of subeconomic resources (location 15, table 1) have been identified (White, $1982 b$, p. 14). Because the bentonitic clay is stratabound (Carman, 1964; Dibblee, 1973; Vedder and others, 1973) and occurs in well prospected areas, the potential for the presence of undiscovered bentonitic clay resources is low.

\section{Borates}

Borates, associated with Miocene basalts and deformed lake and playa deposits, were mined within and near the eastern part of the Sawmill-Badlands RA between 1899 and 1912 (Carman, 1964). Ore at the Russell mine was hand sorted to average 29 to 42 percent $\mathrm{B}_{2} \mathrm{O}_{3}$ (boron oxide) with production from the district totalling about 35,000 tons (Longwill, 1982, p. 8-9). Production ceased around 1913 because of larger and richer deposits developed further east. The grade of ore required for refining or producing beneficiated products is probably not less than 20 percent $\mathrm{B}_{2} \mathrm{O}_{3}$ (Ver Planck, 1957, p. 92). No resources were identified in the Sawmill-Badland RA (Longwill, 1982), but a large boron anomaly marks the locality of the old mines (Smith and others, 1985). Because no other similar anomaly occurs elsewhere in the study area and because the geologic setting is unique to the known boron occurrences, there is no evidence for the presence of undiscovered boron resources elsewhere in the study area.

\section{Building stone}

Active mining is in progress at the Colson quarry, adjacent to the Horseshoe Springs RA (location 5 , table 1), where about 2,000 tons of flagging and rubble are produced annually from thin-bedded, fine-grained sandstone and interbedded siltstones of the Miocene Monterey Formation. These rocks extend a mile northwest and southeast into the Horseshoe Springs RA and include in excess of $50,000,000$ tons of raw material (Horn, 1983; $\mathrm{p}, 4$ ). Although sandstone has been identified in other roadless areas (Sespe-Frazier RA, Hale and others, 1983; Dry Lakes RA, White, 1982a; Matilija RA, Lambeth, 1982), these have not been shown in table 1 because large amounts of potentially suitable rock are available thoughout the Transverse Ranges, both inside and outsid: the study area. Existing quarries have good supplies and are located closer to markets. However, other localities in the study area containing sandstone are described in a companion map (U.S. Bureau of Mines, 1985).

Marble and dolomitic marble are present in the Antimony RA. A total of about 85 million tons of this material is identified at the Lebec and White Rock properties (locations 13, table 1; Kuizon, 1981, table 1, Nos. 3, 17). Hart (1978, p. 94) describes the Sierra Blanca Limestone, a commercial-grade rock, which crops out in the study area wert of Wheeler Hot Springs. Steeply dipping bands of marble and calc-silicate rock $6 \mathrm{mi}$ east of Sespe Hot Springs (Frizzell and Vedder, 1985) are thin and inaccessible.

\section{Copper and zinc}

A copper and zinc occurrence is present near Wildhorse Mountain (location 7, table 1) in the La Brea RA. Gabbroic rocks, part of the dismembered Coast Range o phiolite (an association of dark-colored igneous and sedimentary rocks formed in oceanic areas), contain vugs and fractures filled with malachite, azurite and associated dissemirated sulfide minerals. This mineralization may have occurred by remobilization and precipitation of syngenetic copper in the gabbro (Smith and others, 1985). Prospects in a high-zrade zone contain 1,300 tons of gabbro with 1.87 percent ecrper and 3.13 percent zinc. An additional 5,850 tons of gebbro containing 0.18 percent copper and 1.34 percent zinc are present nearby (Benham and MeCulloch, 1981, p. 4).

Although copper occurrences are reported in the Sespe-Frazier RA (Weber and others, 1973, p. 65), we found no geochemical indications of a potential for the occurrence of the metal there or elsewhere in the study area.

\section{Geothermal resources}

Thermal springs form a linear pattern in the southern part of the study area along the Santa Ynez fault system (Muffler, 1979, map 1). Temperatures of spring waters ir and near the Diablo, Dry Lakes, and Matilija RAs range between $62^{\circ} \mathrm{F}$ and $118^{\circ} \mathrm{F}$ (White, 1982a; Lambeth, 1982; Godwir and Stephens, 1979), and portions of these RAs have been cl'ssified as lands valuable prospectively for geothermal resources. Although data are insufficient to estimate rese'voir parameters, these springs probably only have potential for non-electric, or direct heat, purposes.

Sespe Hot Springs, in the Sespe-Frazier RA, forms the eastern termination of the linear pattern of springs and is classified as a "Known Geothermal Resource Area" (a KGRA; Muffler, 1979 , map 1). Temperatures of waters from the four springs in this hot-water hydrothermal convection system range to $194^{\circ} \mathrm{F}$ (Brook and others, 1979, table 6, No. 61) and subsurface temperatures of source aquifers probably range between $230^{\circ} \mathrm{F}$ and $270^{\circ} \mathrm{F}$ (McCulloh and others, 1981, p. 359). Although these springs have potential for direct heat use, their remote location limits their usefulness for this purpose.

\section{Lode gold}

Lode gold was discovered in the late 1800 's at the Castaic mine (location 2, table 1) and Frazier mine (outside study area) in or near the Sespe-Frazier RA and at the F'ack Bob mine (location 14, table 1) in the Antimony RA. Gold production of about 1300 oz was reported from the late $1800 \mathrm{~s}$ until 1942 from mines in the Sespe-Frazier RA (Hale and others, 1983, p. 9). Small amounts of gold, silver, and lead were produced from the Black Bob mine in the early 1900 's (Kuizon, 1982, p. 7).

Gold prospects and former mines are locally found in quartz veins along shear zones in Precambrian gneiss ir the Sespe-Frazier RA. The gold in one mine, outside the study area west of Frazier Mountain and not examined in this study, apparently occurs as disseminated particles in gossan-rich 
shear zones and is associated with iron sulfides (Carman, 1964 , p. 60). In the Sespe-Frazier RA, similar quartz veins along shear zones are mostly one to several feet thick and trend northwesterly (Hale and others, 1983).

Although at least a trace of gold occurs in 12 of the 17 gold prospects and mines examined in or near the SespeFrazier RA (Hale and others, 1983), we were able to establish identified resources for only one locality because many of the workings are caved and not well enough exposed to determine resources and reserves. Of the 266 samples collected from 17 gold prospects or former gold mines in or near that roadless area, about 22 percent ( 58 samples) con-ained a trace or more gold (Hale and others, 1983, tables 2, 3. Data discussed below resides in this reference.). Thirty of 115 samples from four prospects and mines on the west side of Frazier Mountain (Dom Bosco, Esperanza, Jewel, and White Mule) contained from a trace to $0.22 \mathrm{oz}$ gold/ton (all but the one contained $0.08 \mathrm{oz}$ gold/ton or less). Four of 12 samples from two prospects and mines (Gold Dust and Hidden Value) southeast of Frazier Mountain contained from 0.046 to $0.316 \mathrm{oz}$ gold/ton. Eight of 28 samples from an unknown prospect in Lockwood Creek contained from 0.026 to 0.072 oz gold/ton. Of ten samples from the Brown prospect, nine yielded no significant values, and one contained $0.31 \mathrm{oz}$ gold/ton; of 40 samples collected from the Gold Hill Group, 36 yielded no significent gold values, three contained trace to $0.012 \mathrm{oz}$ gold/ton, and one contained $0.122 \mathrm{oz}$ gold/ton. Eight of 24 samples from the Castaic mine (location 2, table 1) yielded gold values: six samples from a massive quartz vein assayed 0.02 to 1.2 $o z /$ ton. This quartz vein contains about 8,000 tons of indicated and inferred subeconomic resources averaging $0.38 \mathrm{oz}$ gold/ton (Hale and others, 1983, table 1, No. 26). Although the gold bearing veins in the Frazier mine may extend into the roadless area (Hale and others, 1983, table 2, No. 52), and although the Harris mine contains anomalous gold values (Smith and others, 1985), we are unable to establish identified resources with significant gold values for any other mine or prospect within the Sespe-Frazier RA except the Castaic mine. Potential is low to moderate for the presence of additional undiscovered lode gold resources in this roadless area.

Gold at the Black Bob and Cedar mines (location 14, table 1 ) in the Antimony RA is found in quartz veins along shear zones, but these shears are in Mesozoic biotite granodiorite, not in Precambrian rocks as they are in the SespeFrazier RA. Heavy-mineral concentrates taken downstream from the mines show strong arsenic and tin anomalies (elements of ten associated with gold), but rock sampling indicates only the known gold locality in that drainage (Smith and others, 1985). These mines contain 1,600 tons of marginal reserves averaging $0.13 \mathrm{oz} /$ ton gold and 11,000 tons of subeconomic resources averaging $0.034 \mathrm{oz} /$ ton (Kuizon, 1982, p. $4,13)$.

Anomalies in antimony, arsenic, tungsten, mercury, boron, silver, and gold from Antimony Peak (location 12, table 1 ) indicate the previously known antimony deposits and suggest possible gold mineralization (Smith and others, 1985). Jermain and Ricker $(1949$, p. 5) reported gold and silver values of $\$ 0.60$ per ton. Seven chip samples contained gold ranging from trace to $0.29 \mathrm{oz} /$ ton (Lucia Kuizon, unpub. report, 1982). Low to moderate potential exists for the presence of undiscovered gold resources in the vicinity of Antimony Peak.

From a total of 74 chip samples collected from the Deer Trail mine just outside the Stanley Mountain RA, two samples contained gold values of 0.014 and $0.026 \mathrm{oz} / \mathrm{ton}$ (Kuizon, 1983d, p. 6). Four chip samples from the Clyde's Saylor prospect in the Machesna Mountain RA contain gold ranging from 0.01 to $0.06 \mathrm{oz} /$ ton (Kuizon, $1983 \mathrm{~b}$, p. 9 ).

Low potential exists for the presence of undiscovered lode gold resources elsewhere in the study area.

\section{Placer gold}

Placer gold mining by Spanish settlers and Indians began in the region in the early 1800's in the La Panza mining district, partly within the La Panza, Machesna Mountain, and Black Mountain RAs. Total gold production in this district is estimated at $\$ 200,000$ (Clark, 1970, p. 179). In the early 1840's placer gold was mined from Piru Creek in the SespeFrazier RA.

Many of the generally small and discontinuous nuaternary(?) and modern terrace and stream gravel deposits were sampled for placer gold (see various references, table 1; U.S. Bureau of Mines, 1985). Calculated grade for incividual samples ranges from none detected to $0.015 \mathrm{oz}$ gold $/ \mathrm{cu}$ yd with grades on significant volumes of gravel averaging less than $0.002 \mathrm{oz}$ gold/cu yd. Localities within the study area with appreciable volumes of gravel include: the Luc'ey Girl placer on the boundary of the La Panza RA with about 15,000 cubic yards of terrace and stream gravel (about 3,000 cubic yards are in the La Panza RA) averaging 0.0002 oz gold/cu yd (Barnes, 1981); the Jehovah Jireh property in the Mechesna Mountain RA with about 27,000 cubic yards of bench gravels that average $0.002 \mathrm{oz}$ gold/cu yd (Kuizon, 1983b, p. 8); and the CIC placer on Piru Creek in the Sespe Frazier FA that contains about 82,000 cubic yards with less than $0.0005 \mathrm{oz}$ gold/cu yd (Hale and others, 1983). The general low grade and discontinuous occurrence of placer gold within the study area probably precludes recovery of the gold by commercial ventures, but does not necessarily preclude recovary by hobbyists. Low potential exists for the presence of undiscovered placer gold resources in the study area.

\section{Gypsum}

Gypsum was discovered in the Cuyama RA ir 1892. Subsequently, other gypsum deposits were discovered in and near the Cuyama, Sawmill-Badlands, Sespe-Frazie", and Quatal RAs. Two deposits (Frenchman's Point and Burgess Canyon) in the Sawmill-Badlands RA contain thin, impure gypsum-bearing zones, but no resources were identified (Longwill, 1982). Several claims for gypsum were filed in or near the Fox Mountain RA as early as 1901 (MeCullceh and Neumann, 1982), but no resources were identified. The Monolith Quarry, just west of the Quatal RA, produced ab jut 1.7 million tons of gypsum and gypsite between 1939 and 1980 (White, 1982b, p. 7). A small amount of gypsum of the alabaster variety was mined for local use in the 1950's through 1970 's from the Cuyama and Sawmill-Badlands RAs.

Gypsum occurs as discontinuous beds or lenses interbedded in Neogene sandstone and siltstone sequences interpreted to have been deposited in hypersaline lagoonal to very shallow marine environments (Thor, 1978, p. 52-54) and saline lakes. Three prospects in the Cuyama RA (locations 9,10 , 11, table 1) are estimated to collectively contain about 370,000 tons of subeconomic gypsum resources that average between 83 to 90 percent $\mathrm{CaSO}_{4}$ (calcium sulfate) ( $\mathrm{F}^{\prime}$ uizon, 1981 , p. 9). Gypsum-bearing beds occur both inside and outside the Sespe-Frazier RA near Pine Mountain (locetion 3 , table 1). About 8 million tons of subeconomic gyps im resources, averaging 76 percent $\mathrm{CaSO}_{4}$, occur within the latter roadless area (Hale and others, 1983, p. 16).

Because the gypsum is stratabound and occurs in well prospected areas, the potential for the presence of undiscovered gypsum resources is low.

\section{Mercury}

Mercury was discovered north of the Santa Lucia Wilderness (at the Rinconada mine) in 1872 and adjacent to the Stanley Mountain RA (at the Deer Trail mine) ir 1914. Total production from the Rinconada and Deer Trail mines was about 3,000 and 200 flasks of mercury (a flask contains 76 pounds of mercury), respectively (U.S. Bureau of Mines, 1965 , p. 165).

Mercury deposits in California are generally associated with major fault zones and, in many places, with young volcanic systems. Hot fluids containing mercury apparently move through the crushed rock and fill openings or replace host rocks as local changes in pressure, temperature, and chemistry permit.

The Rinconada mine produced mercury from silicacarbonate rock, an altered form of serpentinite, that formed prior to the mercury mineralization (Eckel and others 1941, p. 531). This mine was one of the largest producers in San 
Luis Obispo County and yielded ore containing about 5 to 10 lbs of mercury per ton (Eckel and others, 1941, p. 536). Rocks similar to those at the mine do not occur in the Santa Lucia Wilderness (Sabine and Esparza, 1981). Mercury occurs as cinnabar which fills fractures in brecciated calcite at the Deer Trail mine. The mine contains about 32,000 tons of vein calcite and sandstone averaging $1.71 \mathrm{lbs}$ mercury/ton (Kuizon, 1983d, p. 10). Low to moderate potential exists for the presence of low-grade mercury resources in and adjacent to this mine. Low potential exists for the presence of undiscovered mercury resources in other parts of the study area.

\section{Petroleum}

Oil and gas exploration began in the region in the 1860 's, and the first wells were drilled in the Sespe Creek area in 1887 (Kew, 1924, p. 121). The Sespe oil field, part of which is in the Sespe-Frazier RA, has produced 24 million barrels of oil and 22 billion cubic feet of gas since it's discovery, and it currently produces 96 percent of the production within the boundaries of the Los Padres National Forest $(700,000$ barrels of oil and 900 million cubic feet of gas in 1981, Hollis Record, written commun., 1982).

Wildeat drilling and oil and gas production in and near the study area have not been very successful. Of the approximately 222 classifiable holes completed outside known oil and gas fields through 1981, about 214 were dry holes, and less than 80,000 barrels of oil were pumped from the eight producing wells, all of which are now abandoned or idle (Frizzell and Claypool, 1983). These statistics are not surprising when the organic geochemistry of the rocks in the study area is reviewed. These data indicate that most preMiocene rocks sampled contain less than 1 percent total organic matter (Frizzell and Claypool, 1983), most of which has little capacity to generate oil (although it may generate natural gas).

Samples from Miocene and younger marine rocks, however, indicate that they have about 2 percent organic matter of a type that does produce oil and gas. Most localities underlain by Miocene and younger marine rocks, though, are either composed of relatively thin sequences of these rocks or contain sections that have been breached by erosion, thus allowing the escape of any entrapped oil and gas. (Hydrocarbon-bearing fluids generally travel upward through minute holes in rocks. They can be trapped against various types of impermeable zones or layers, but if the porous rocks crop out at the earth's surface, any fluids that may have been using the rock as a conduit will be lost.)

For instance, the southern two-thirds of the Santa Lucia Wilderness is underlain by Miocene marine rocks that appear to be about $5,000 \mathrm{ft}$ thick in which canyons as deep as $1600 \mathrm{ft}$ have been cut. Similarly, the Miocene rocks exposed at the surface in the Tepusquet Peak, La Brea, and Little Pine RAs are apparently relatively thin (about 2,000 to 4,000 $\mathrm{ft}$ ) and generally have been deeply dissected by erosion.

Although the Miocene rocks at the surface in the Fox Mountain RA are relatively thin and have been deeply dissected, similar rocks have been projected to occur below the low angle South Cuyama fault northwest of the roadless area. However, if this fault is present in the roadless area, gravity data do not support the presence of appreciable thicknesses of Neogene rocks below it (Griscom, 1985b).

An elongate, east-west negative-gravity anomaly confirms the presence of Miocene rocks below the San Cayetano thrust in the southernmost part of the SespeFrazier RA. South of the line labled A-A' (fig. 3), the fault may be less than $12,000 \mathrm{ft}$ below sea level (Griscom, 1985b). Another, smaller, negative-gravity anomaly may indicate that Miocene and younger rocks are present below the Pine Mountain fault, and a small part of this anomaly is present in the roadless area near Pine Mountain (Griscom, 1985b).

In summary, drilling experience and organic geochemical data indicate a low potential for the presence of undiscovered oil and gas in pre-Miocene rocks outside known fields. A low to moderate potential for the presence of undiscovered oil and gas in marine Miocene and Pliocene sedimentary rocks is indicated by favorable organic geochemical data but variable physical settings. The most favorable settings, which have moderate potential for the presence of oil and gas, exist below the San Cayetano, and, perhaps, the Pine Mountain faults. Late Eocene marine, Oligocene nonmarine, and Neogene marine rocks near evisting oil and gas fields in and near the southern part of the SespeFrazier RA still probably contain additional oil and gas.

\section{Phosphate rock}

Phosphate-rock occurrences were first reported in Ventura County in 1925 and Santa Barbara County in 1؟31. In the 1960's, two phosphate deposits, one at Pine Mcuntain (location 3, table 1) adjacent to and in the Sespe-Fraz'or RA and the second at the Cuyama deposit (location 8, table 1) adjacent to the Fox Mountain RA, were extensive'y explored. The Cuyama phosphate mine produced 18,000 tons of phosphate rock between 1965 and 1970 (McCulloch and Newmann, 1982, p. 6).

Phosphate pellets were probably precipitated in a Neogene offshore muddy shelf environment that had both a low sedimentation rate and optimal chemical envircnment (Thor, 1978, p. 47-48). The Fox Mountain RA may contain more than 300 million tons of phosphatic pellet-bearing rocks (Fedewa and Hovland, 1981 , p. 72), but most of these rocks are covered by thick overburden. The area (location 8 . table 1) does, however, contain more than 21 million tons of subeconomic phosphate-rock resources with 4.84 percent $\mathrm{P}_{2} \mathrm{O}_{5}$ (phosphorous pentoxide), which are not as deeply buried (MeCulloch and Neumann, 1982, p. 4).

Phosphate-bearing beds occur both inside and outside the Sespe-Frazier RA near Pine Mountain (location 3, table 1). About 51 million tons of phosphate- rock reserves averaging 10 percent $\mathrm{P}_{2} \mathrm{O}_{5}$, occur within the study area (Hrle and others, 1983). This phosphate rock deposit is minable under 1982 conditions, assuming a hypothetical one million ton per year open-pit mining operation utilizing advaneed technology in the processing operation. By comparison, 18 percent $\mathrm{P}_{2} \mathrm{O}_{5}$ represented the minimum grade of phosphate-bearing rock for earlier resource estimates with different economic contitions in the Permian phosphate fields in Wyoming where more than 25 billion tons of reserves occur (Sheldon, 1963, p, 148, table $20)$. Because the phosphate is stratabound and occurs in well prospected areas, the potential for the presence of undiscovered phosphate-rock resources in the study area is low.

\section{Rock products}

A variety of unconsolidated materials, includinf relatively well sorted alluvial gravel, sand, and silt, underlie major river and sidestream valley bottoms througho"t the study area. Although these materials can be used for construction purposes, they are not specifically identified herein. Because there are abundant deposits of these materials outside the study area, deposits in the study area cannot compare favorably with those closer to major markets.

\section{Silver}

Although silver does not occur as the primary matal of interest at any prospect in the study area, it does occur associated with gold-bearing veins in both the Sespe- $\Gamma$ razier and Antimony RAs. Selected samples from prospects in or near the Sespe-Frazier RA contain silver values rangin from 0.4 to $0.6 \mathrm{oz}$ silver/ton, but since many workings are caved and not well enough exposed, no tonnages are assigned (Hale and others, 1983). The 1,600 tons of marginal reserves at the Black Bob and Cedar mines in the Antimony RA (locat' in 14, table 1) average $0.5 \mathrm{oz} /$ ton silver and the 11,000 tons of subeconomic resources average $0.27 \mathrm{oz} /$ ton silver (F'uizon, 1982).

From a total of 74 chip samples collected, two s?mples from the Deer Trail mine adjacent to the Stanley Mountain RA contained silver values of 2.4 and $3.3 \mathrm{oz} /$ ton silver (Kuizon, 1983d, p. 6). Two chip samples from Clyde's Saylor prospect in Machesna Mountain RA contained silver ranging from 0.1 to $0.3 \mathrm{oz} /$ ton (Kuizon, 1983b, p. 9). Low potential exists for the presence of undiscovered silver resources in the study area. 


\section{Uranium}

Uranium minerals were first reported in the Antimony, Sawmill-Badlands, Machesna Mountain, and Black Mountain RAs in the 1950's. In the Black Mountain RA, biotite schist, which has been intruded by granitic rocks, loeally shows scintillometer readings four to five times regional background. The uranium associated with these schists locally averages $90 \mathrm{ppm}$ uranium while the sitieffied granitic rocks average $6 \mathrm{ppm}$ uranium (Smith and others, F985). The Black Widow prospect (location 4, table 1) has produced about 400 lbs of $\mathrm{U}_{3} \mathrm{O}_{8}$ (uranium oxide); it and two nearby prospects contain about 153,000 tons of subeconomic uranium resources averaging $0.02-0.047$ percent $\mathrm{U}_{3} \mathrm{O}_{8}$ and 2,900 tons indicated and inferred uranium resources averaging $\mathbf{0 . 1 8}$ percent $\mathrm{O}_{3} \mathrm{O}_{8}$ (Gabby, 1981, table 1). Low to moderate patential exists for the presence of undiscovered low-grade uranium resources at depth at these sites.

The Clyde's Saylor prospect in the Machesna Mountain RA is in a geologic setting similar to that in the Black Mountain RA, but no resources were identified. Three chip samples from the prospeets contained $0.009,0.013$, and 0.029 percent $\mathrm{U}_{3} \mathrm{O}_{8}$ (Kuizon, 1983b, p. 9).

Metasedimentary rocks occur as seattered roof pendants in the Brush Mountain aree in the Antimony RA. Metasandstone and quarterte at the CL and Brush claims contain anomalous uranium and gold (13 samples contain 0.001 to 0.046 percent $\mathrm{U}_{3} \mathrm{O}_{8}$; six contain trace to $0.069 \mathrm{oz}$ gold/ton) and seintillometer readings 8 to 10 times regional backgroumd (Smith and others, 1985; Kuizon, 1982; Troxel and Morton, 1962 , p. 341, no. 673). The data are insufficient, however, to estimate resources. Low potential exists for the presence of undiscovered uranium resources in basement rocks in the study area.

In addition to occurring in igneous and metamorphic rocks, uranium has also been sought in Tertiary sedimentary rocks. The contact between the marine Coldwater Sandstone and the overlying nonmarine Sespe Formation, in partieular, has been prospected for uranium because of an occuirence (Bowes and Myerson, 1957) west of Ojai, outside the study area, of uranium-bearing minerals in lenses and coneretions commonly associated with carbonaceous material (Dickinson, 1982). Similar oecurrences have been noted near Hartman ranch where carbonaceous samples contain as much as 0.8 percent $\mathrm{U}_{3} \mathrm{O}_{8}$ (Dickinson, 1982). The Sespe-Coldwrater contaet at and near this locality is more abrupt than near Ojai. and the mineralization model proposed by Diekinson (1982) probably does not apply. Other localities in or near the study area that contain minor uranium minerals gre noted in Dickinson (1982) and Dickinson and others (1982). There is 8 low potential for the presence of undiscovered uranium resources in Tertiary sedimentary rocks in the study area.

\section{SUMMARY ASSESSMENT OF MINERAL. RESOURCE POTENTTAL}

Although we have identified antimony, barite, bentonitic clay, building stone, gold, gypsum, phosphate rock, and uranium resources and noted loealities with potential for mineral resources, the geologic and geochemical data only indicate a low potential for the presence of undiscovered resources. Some parts of some roadless areas, however, have a low to moderate potential for the presence of speeific undiscovered mineral commodities. Not noted for individual roadless areas, but present throughout the study area are: (1) low to moderate potential for the presence of undiscovered petroleum resourees in areas underlain by Miocene and younger sedimentary rocks, and (2) low to moderate potential for the presence of undiscovered barite resources.

\section{Sespe-Frazier Roadless Area No. 5002}

No mining is taking place in the Sespe-Frazier RA, although over 400 mining elaims have been located there since 1885. Current mining claims include 152 unpatented placers and lodes, one patented lode, and five millsites (Hale and others, 1983, p. 9). Gold production, totaling about 1300 oz, terminated in the roadless area in 1941. Gypsum has been prospected since 1964, and a phosphate prospecting rormit extends into the roadless area near Pine Mountain ( $\mathrm{Ha}^{\mathrm{l}} \mathrm{e}$ and others, 1983). Petroleum has been produced at the Sespe Canyon Field since before the turn of the century.

Although the gold bearing veins in the Frazier mine may extend into the roadless area and although twelve $f$ rmer mines or prospects contain greater than trace amounts of gold (Hale and others, 1983, tables 2 and 3), gold resnurces could only be identified at one locality mainly because many workings were caved and not well enough exposed to determine resources. Eight thousand tons of indicated and in erred subeconomic gold resources averaging $0.38 \mathrm{oz}$ gold per ton occur at the Castaic mine (location 2, table 1) (Hal? and others, 1983, table 1, No. 26). Identified subeconomic lode gold resources at the Castaic mine do not contain enough gold-bearing quartz, though, to justify the cost of miniry and building a concentrating mill. If a mill which accepter custom ore were present nearby, potential for development of the Castaic deposit would be enhanced. Potential is low to moderate for the presence of undiscovered gold resnurces near mines and prospects in the northern part of the SespeFrazier RA.

Several localities are underlain by stream and terrace gravel and sand that have been investigated as possible sources of placer gold, where deposits range from 1000 cubic yards averaging $0.004 \mathrm{oz}$ gold/cu yd to 540,000 cubic yards averaging $0.0003 \mathrm{oz}$ gold/cu yd (Hale and others, 1983, table 2, No. 16, 20, 21, 22 and 33). These placer gold occurrences are subeeonomic because of low gold values and general' $y$ low volume and are not shown on fig. 3 . Some of the occurrinces, however, may be attractive for recreational pannin? and small portable dredging operations. Potential is low for the presence of undiscovered placer gold resources in the SespeFrazier RA.

Bentonitic clay has been produced from the Lociewood Clay of Neogene age just north of the roadless area since 1954. This unit extends into the northwest part the study aree (location 1, table 1). A reserve of 7.2 million tons has been caleulated for this prospect, of which 4.7 million tons oceurs inside the roadless area (Hale and others, 1983, p. 17, table 1, No. 13). Bentonitic clay at this prospect is subeconomic beeause the mine adjacent to the roadless arra has enough reserves to keep the clay plant supplied for 150 to 200 years at the 1981 rate of lightweight aggregate prodiction (Hale and others, 1983, p. 17). Potential is low for the presence of undiscovered bentonitic clay resource in the SespeFrazier RA.

About 117 million tons of phosphate-rock resarves, averaging 10 percent $\mathrm{P}_{2} \mathrm{O}_{5}$ (phosphorous oxide), and $13 \mathrm{mil}-$ lion tons of subeconomic gypsum resources, averaging 76 percent $\mathrm{CaSO}_{4}$ (calcium sulfate), have been identified near Pine Mountain (location 3, table 1), and an estimat:d 51 million tons of this phosphate rock and 8 million tons of the gypsum are in the roadless area (Hale and others, 1983, table 2, No. 28). The phosphate-rock deposit is minable under 1982 economic conditions (Hale and others, 1983, p. 18). Low potential exists in the area for the presence of undisecvered phosphate and gypsum resources.

The Sespe-Frazier RA includes parts of the eastern oil fields of the Ventura basin. These fields may ultimately yield in excess of 2 billion barrels of oil (Taylor, 1976, tahle 2) about 82 percent of which comes from late Miocene or younger rocks. Despite relatively low quantity and quality of organic matter in pre-Miocene rocks, such rocks yield about 5 percent of the oil in the Ventura fields. Most of that (4 percent) is from the Oligocene nonmarine Sespe Formation, although Bailey (1947) makes a strong argument thet the source for the Sespe oil is Eocene age rock.

Oil will probably continue to be found in suitable reservoir rocks in the vicinity of the Sespe fields. Potential targets include Miocene and Pliocene rocks below the San Cayetano thrust within the roadless area (most re?ently discussed by Yeats, 1983, fig. 11). South of the line A-A' (fig. $3)$, drilling depths necessary to penetrate the fault are probably less than $12,000 \mathrm{ft}$ below sea level (Griscom, 1985b, after Nagle and Parker, 1971). 
Gravity data suggest that Miocene age rocks may also be concealed below the Pine Mountain fault (Griscom, 1984b). If this is the case, these rocks may be potential drilling targets, although a $9,500-\mathrm{ft}$ well drilled 1 to $2 \mathrm{mi}$ southwest of the gravity anomaly did not penetrate the fault or drill through Eocene rocks. Moderate potential exists for the presence of undiscovered petroleum below the San Cayetano and Pine Mountain faults, low to moderate potential exists for the presence of undiscovered petroleum in Miocene and younger sedimentary rocks, and the potential is low for the presence of undiscovered oil in other parts of the roadless area.

Sespe Hot Springs is a hot-water hydrothermal convection system and has reservoir temperatures between $230^{\circ}$. $270^{\circ} \mathrm{F}$ (McCulloh and others, 1981, p. 359). Although these springs have potential for direct heat use, their remote location limits their usefulness for those purposes.

Mica and molybdenum occurrences have been noted in the Sespe-Frazier RA (Tucker and Sampson, 1932, p.269 and p. 257), but exposures were not sufficient to determine their resource potential (Hale and others, 1983).

There is low potential for the presence of undiscovered resources for other mineral commodities in the Sespe-Frazier RA.

\section{Garcia Mountain Roadless Area No. 5107}

Although 28 mining claims have been located in the roadless area in the past, no mines were developed (Lipton, 1981, p. 6-7). Placer sampling indicated gold occurrences in trace quantities within the study area, but no significant volume of alluvium exists.

There is low potential for the presence of undiscovered mineral resources in the Garcia Mountain RA.

\section{Black Mountain Roadless Area No. 5108}

There are currently about 69 lode claims for uranium located in the roadless area. About 400 lbs of $\mathrm{U}_{3} \mathrm{O}_{8}$ (uranium oxide) was probably produced at the Black Widow prospect (Gabby, 1981, p. 8-9). The Black Widow and Black Widow Extension (both at location 4, table 1) contain about 2,900 tons of inferred subeconomic resources averaging 0.18 percent $\mathrm{U}_{3} \mathrm{O}_{8}$, and 78,000 tons of inferred subeconomic uranium resources averaging 0.02 percent $\mathrm{U}_{3} \mathrm{O}_{8}$ (Gabby, 1981, table 1). An unnamed prospect to the east of the Black Widow (also represented by location 4, table 1) has 75,000 tons of inferred subeconomic resources averaging 0.047 percent $\mathrm{U}_{3} \mathrm{O}_{8}$ (after Gabby, 1981, p. 9-11). Low to moderate potential exists for the presence of low-grade uranium resources at depth at these localities, but low potential exists for the presence of other undiscovered mineral resources in the Black Mountain RA.

\section{La Panza Roadless Area No. 5109}

Twenty-nine mining claims, including 13 gold placer claims, have been located within the roadless area. Evidence of prospecting was found only at the Lucky Girl prospect (mostly outside the roadless area) where an estimated 15,000 cubic yards of sand and gravel deposits (about 3,000 cubic yards are in roadless area) with a gold content of $0.0002 \mathrm{oz}$ gold/cu yd were found (Barnes, 1981, p. 4, 8-9). There is low potential for the presence of undiscovered mineral resources in the La Panza RA.

\section{Machesna Mountain Roadless Area No. 5110}

Current mining activity within and near the roadless area includes uranium prospecting and small-scale gold placer operations. Approximately 200 placer and 300 lode claims have been located in the Machesna Mountain area since the late 1800 's, and there are currently 21 gold placer and 20 uranium lodes located there (Kuizon, 1983b, p. 6-7).

Approximately 27,000 cubic yards of placer gold materials that may average 0.002 oz gold/cu yd have been estimated for the Jehovah Jireh prospect (Kuizon, 1983b, p. 8).
Uranium occurrences in and near the study area are sporadic and discontinuous, and low potential exists for the presence of uranium resources at depth (Kuizon, 1983b, $p$. 8). There is low potential for the presence of undiscovered mineral resources in the Machesna Mountain RA.

\section{Los Machos Hills Roadless Area No. 5111}

Six lode and four placer mining claims were locatec within or adjacent to the roadless area between 1864 and 1930. There are no active mining claims, patented claims, or mineral leases. About 4,500 cubic yards of stream and terrace deposits, containing a trace of gold, were found at an olc placer prospect immediately outside the roadless are $\varepsilon$ (Denton, 1982, p. 4, 6-7). There is low potential for the presence of undiscovered mineral resources in the Los Machor Hills RA.

\section{Big Rocks Roadless Area No. 5112}

There are no current mining claims within the roadless area. Three lode claims located in 1955, possibly for uranium, were not found in the field. There are eight oil and gas lease applications filed, but no drilling has resulted (Kuizon 1983a, p. 6).

Phosphate and gypsum deposits have been found in the Santa Margarita Formation of Neogene age in and near other roadless areas in the study area, and although this formatior crops out in the northwest and southeast parts of the roadlesr area, no phosphate or gypsum was found (Kuizon, 1982a, p 6). There is low potential for the presence of undiscovered mineral resources in the Big Rocks $R A$.

\section{Stanley Mountain Roadless Area No. 5113}

There have been at least 29 unpatented lode and placer claims and one millsite located in and near the roadless are (Kuizon, 1983d, p. 9). Seven oil placer claims were located near the northwest corner of the roadless area, one within it: boundary. One gold(?) placer claim is located in the roadles: area. One oil and gas lease application and part of another have been filed near the northeast corner of the study area (Kuizon, 1983d). Five lode claims and the millsite for the Deer Trail Mercury mine are adjacent to the west boundary. The Deer Trail mine contains about 32,000 tons of sandstone and vein calcite averaging $1.71 \mathrm{lbs}$ mercury/ton (Kuizon. 1983d, p. 10). The Stanley Mountain RA has low to moderate potential for the presence of low-grade mercury resourcer near the mine, but has low potential for the presence of other undiscovered mineral resources.

\section{Miranda Pine Roadless Area No. 5114}

Seven mining claims, possibly for uranium, were located along the southern boundary of the roadless area in the late 1950 's. Two oil and gas lease applications are filed in the eastern part of the roadless area. No evidence of minine activity was found in the study area (Kuizon, 1983c, p. 6), There is low potential for the presence of undiscovere mineral resources in the Miranda Pine RA.

\section{Horseshoe Springs Roadless Area No. 5115}

Mining is taking place at the Colson Stone quarr: (location 5, table 2) adjacent to the southern part of thi roadless area, where about 2,000 tons of dimension stone used as flagstone and rubblestone are being produced per yea" from the Monterey Formation. There are about 3.3 million tons of reserves at the quarry, and sandstone that extends fo" about $2 \mathrm{mi}$ into the roadless area contains about 50 million tons of inferred marginal reserves (Horn 1983, p. 4). Low potential exists for the presence of undiscovered mineral resources in the Horseshoe Springs RA.

Tepusquet Peak Roadless Area No. 5116

No evidence of mining activity (Avery, 1981, p. 4-5) oa potential for the presence of undiscovered mineral resources, was found in the Tepusquet Peak RA. 
La Brea Roadless Area No. 5117

Eighty-seven mining claims have been located in this roadless area. Six claims containing copper and zine are present at Wildhorse Mountain (location 7, table 1 ) in a gabbroic member of the dismembered Coast Range ophiolite, but they are currently inactive. The prospect is estimated to contain more than 7,000 tons of ultramafic rock averaging $\mathbf{0 . 5}$ percent copper and 1.7 percent zine (Benham and MeCulloch, 1981 , p. $4,6-7)$. The potential for the presence of undiscovered copper and zine resources is low.

Four thousand tons of barite were produced from veins in sandstone at the patented White Elephant mine (location 6 , table 1) in 1929 and 1930. About 95,000 tons of inferred subeconomic resources averaging 73 percent barite $\left(\mathrm{BaSO}_{4}\right)$ are present there (Benham and McCulloch, 1981, p. 4, 7-8). Low potential exists for the presence of other undiscovered mineral resources in the La Brea RA.

\section{Spoor Canyon Roadless Area No. 5118}

There are no active mines in or near the study area, nor have any mining claims been located in the area. Twelve oil and gas lease applications occur within the roadless area boundaries (Benham, 1983, p. 4). Low potential exists for the presence of undiscovered mineral resources in the Spoor Canyon RA.

\section{Fox Mountain Roadless Area No. $\mathbf{5 1 2 0}$}

The Cuyama Phosphate mine, just north of the roadless area, produced phosphate rock for soil conditioner between 1965 and 1970; reported production totaled about 18,200 tons (MeCulloch and Neumann, 1982, p. 6). The phosphate-bearing rock occurs in the Santa Margarita Formation, which extends into the roadless area (location 8 , table 1 ) where more than 21 million tons of inferred subeconomic phosphate rock resources with an average of 4.84 percent $\mathrm{P}_{2} \mathrm{O}_{5}$ (phosphorous oxide) (McCulloch and Neumann, 1982, p. 6, 8) are identified. Another 18 million tons of phosphate rock of similar grade occur outside the roadless area.

Numerous oil and gas wells have been drilled in the roadless area, but there is no known production (MeCulloch and Neumann, 1983, p. 7). Miocene rocks that may contain petroleum have been projected below the South Cuyama fault by some geologists, although gravity data do not support their presence in great thickness (Griscom, 1985b). If present, these rocks could be a source and a reservoir for oil and gas.

Low potential exists for the presence of undiscovered mineral resources in the Fox Mountain RA.

\section{Diablo Roadless Area No. 5127}

Field investigations revealed no claims, prospects, or mineralized areas (Capstick and Hyndman, 1982a, p. 4) within the roadless area. The Agua Caliente hot springs within the roadless area has temperatures of $90^{\circ} \mathrm{F}$ and has been used for direct heat purposes (Godwin and Stephens, 1979). Low potential exists for the presence of undiscovered mineral resources in the Diablo RA.

\section{Matilija Roadless Area No. 5129}

About 33 mining claims have been located in the roadless area but no mines have been developed (Lambeth, 1982 , p. 8,10 ). Several warm springs within the roadless area near and along the Santa Ynez fault have temperatures between $65^{\circ} \mathrm{F}$ and $116^{\circ} \mathrm{F}$. Data are not sufficient to estimate the sizes or temperatures of the reservoirs (Lambeth, 1982 , p. $4,11-12$ ). The Sierra Blanca Limestone is exposed in Matilija Canyon and extends into the roadless area (Hart, 1978, p. 94).

Low potential exists for the presence of undiscovered mineral resources in the Matilija RA.

\section{Dry Lakes Roadless Area No. $\mathbf{5 1 3 1}$}

There are no producing mines or active prospects within the Dry Lakes Roadless Area (White, 1982a). Wheeler Hot Springs, situated along the Santa Ynez fault zone, has a recorded surface temperatures ranging between $62^{\circ} \mathrm{F}$ t $>118^{\circ}$ F. Potential geothermal resources indicated by such temperatures could be used for direct-heat purposes (White, 1982a, p. $12,13,15)$.

Low potential exits for the presence of undisesvered mineral resources in the Dry Lakes RA.

\section{Sawmill-Badlands Roadless Area No. $\mathbf{5 1 3 4}$}

About 388 claims have been staked within the rcadless area, for oil, borate, gypsum, clays or uranium (Longwill, 1982 , p. 11).

Borates were produced from three mines on the eastern slope of $\mathrm{Mt}$. Pinos partly within the roadless area. Production ceased around 1913 because larger and richer deposits were developed in eastern California (Long will, 1982, F. 5, 9, 16). The Lockwood Clay crops out in the roadless area but it has never been mined there (Longwill, 1982, p. 9, 16).

Two gypsum deposits (Frenchman's Point and Burges Canyon) in the western part of the roadless area havi been mined for local use. Because the gypsum occurs in thin and discontinuous lenses in shale and sandstone, no ressurce estimates were made (Longwill, 1982, p. 10, 16).

Although anomalous uranium and gold occur"ences were found in the roadless area, their local and spradic nature suggests that potential is low for the preserse of uranium or gold resources (Longwill, 1982, p. 10, 16).

The designation of the western part of the SawmillBadlands as having potential for undiscovered petrole $1 \mathrm{~m}$ is misleading and overstates the potential for that area: the area has been unsuccessfully tested by 20 wildcat wells (Frizzell and Claypool, 1983) and is underlain by nonmarine Miocene and Pliocene sedimentary rocks that have less likelihood of producing oil and gas than do marine rocks of the same age (Link and Smith, 1982).

Low potential exists for the presence of undisenvered mineral resources in the Sawmill-Badland RA.

\section{Cuyama Roadless Area No. 5135}

Gypsum has been prospected in the Cuyama RA since the late 1800 's, and a small amount has been produced for local use. Although numerous uranium claims have been located in the roadless area, there are no current mining claims (Kuizon, 1981, p. 7, 9).

The Santa Barbara Canyon gypsum deposit (lo sation 11 , table 1) contains about 30,000 tons of gypsiferous rock averaging 83 percent $\mathrm{CaSO}_{4}$ (calcium sulfate). At the Wagon Road Canyon and Brush Fence Canyon gypsum deposits (locations 10 and 9 , table 1 ), there are 276,000 tons, averaging 85 percent $\mathrm{CaSO}_{4}$, and 61,000 tons, averaging 90 percent $\mathrm{CaSO}_{4}$, respectively, of indicated subeconomic resources (Kuizon, 1981, p. 9-10).

Low potential exists for the presence of additional undiscovered mineral resources in the Cuyama RA.

\section{Antimony Roadless Area No. 5136}

Current mining claims within the roadless area include two lode gold claims, 17 limestone placer claims, and perts of 55 uranium claims. Small tonnages of antimony ore were produced periodically from the Antimony Peak patented property until the late 1940's. Marble had been produced from a few localities just south of the study area botndary during the 1950's and 1960's. Small quantities of gold, silver, and lead were produced in the early 1900's and 1930's (Kuizon, 1982 , p. 7).

The patented Antimony Peak property (location 12, table 1), situated in the center of the roadless area, contains about 240,000 tons of indicated and inferred margin $>$ reserves, averaging 2.73 percent antimony, and about 230,000 tons of indicated and inferred subeconomic resources, avoraging 1.02 percent antimony. The deposit is marginal because of high mining and beneficiation costs, low grade and frices, and poor access. Low to moderate potential exists for the presence of additional similar antimony resources, and per- 
haps gold, near and east of Antimony Peak (Kuizon, 1982, p. 4, 13; Smith and others, 1985).

About 1,600 tons of marginal gold and silver reserves averaging $0.13 \mathrm{oz}$ gold per ton and $0.5 \mathrm{oz}$ silver per ton occur at the Black Bob and Cedar properties (location 14, table 1). There are an additional 11,000 tons of inferred subeconomic resources averaging $0.034 \mathrm{oz}$ gold per ton and $0.27 \mathrm{oz}$ silver per ton (Kuizon, 1982, p. 4, 13). Low to moderate potential exists for additional gold and silver resources at the Black Bob and Cedar properties.

A total of about 85 million tons of indicated and inferred subeconomic marble and dolomitic marble resources occur within the study area at the White Rock and Lebec properties (locations 13, table 1; Kuizon, 1982, p. 5, 13). These resources may be used for local construction purposes.

Other localities containing iron, manganese, and uranium occurrences (Kuizon, 1982; Troxel and Morton, 1962) were not well enough exposed to determine if resources are present. Low potential exists for the presence of other undiscovered mineral resources within the Antimony RA.

\section{Quatal Roadless Area No. 5268}

Fifty-three unpatented mining claims have been located in the roadless area; of these, 52 were placer claims. There are currently eight claims located for gold and other minerals (White, 1982b, p. 8, 10).

Approximately 1.6 million tons of subeconomic bentonite resources that are suitable for bloating clay in the manufacture of lightweight aggregate and for foundry sand bonding occur within the roadless area (location 15, table 1) in the Lockwood Clay (White, 1982b). 'This deposit is subeconomic because of high production costs due to steeply dipping beds.

Low potential exists for the presence of undiscovered mineral resources in the Quatal RA.

\section{Little Pine Roadless Area No. 5278}

Five mining claims are located in the roadless area (Capstick and Hyndman, 1982b). No metallic or nonmetallic mineral resources have been identified within the Little Pine RA and low potential exists for the presence of undiscovered mineral resources.

\section{Santa Lucia Wilderness NF 905}

Although mines and mineral occurrences exist nearby, there is little evidence of mining or prospecting inside the wilderness.

Claims, sporadically located between 1900 and 1965, were mainly mercury placer claims located between 1900 and 1917. Mineralized and altered zones and host rocks at Rinconada Mine, a past producer of mercury adjacent to the wilderness, do not crop out inside the area (Sabine and Esparza, 1981). Low potential exists for the presence of undiscovered mineral resources in the Santa Lucia Wilderness.

\section{REFERENCES CITED}

Adrian, B. M., Smith, D. B., Vaughn, R. B., and MeDougal, C. M., 1984, Statistical analysis of data on stream sediments, panned heavy-mineral concentrates, and rocks from the Santa Lucia Wilderness Area and roadless areas, southern Coast and western Transverse Ranges, California: U.S. Geological Survey Open-File Report 84-675.

Avery, D. W., 1981, Mineral resources of the Tepusquet Peak RARE II Area (No. 5116), Santa Barbara County, California: U.S. Bureau of Mines MLA Open-File Report 7-81, 6 p.

Bailey, T. L., 1947, Origin and migration of oil into Sespe redbeds, California: American Association of Petroleum Geologists Bulletin, v. 31, p. 1913-1935.

Barnes, D. J., 1981, Mineral resources of the La Panza RARE II Area (No. 5109), San Luis Obispo County, California: U.S. Bureau of Mines MLA Open-File Report $34-81,10 \mathrm{p}$.
Benham, J. R., 1983, Mineral investigation of the Spoor Canyon RARE II Area (No. 5118), Santa Berbara County, California: U.S. Bureau of Mines MLA OpenFile Report, 17-83, 7 p.

Benham, J. R., and MeCulloch, R. B., 1981, Mineral rescirces of the La Brea RARE II Area (No. 5117), Santa Berbara County, California: U.S. Bureau of Mines MLA Openfile Report 9-82, 9 p.

Bowes, W. A., and Myerson, B. L., 1957, Sandstone-type uranium occurrences in White Ledge Peak area, Ventura County, California: U.S. Atomic Energy Commission, RME 2073, 20 p.

Brook, C. A., Mariner, R. H., Mabey, D. R., Swanson, J. R., Guffanti, Marianne, and Muffler, L. J. P., 1979, Kydrothermal convection systems with reservoir temperatures $90^{\circ} \mathrm{C}$, in Muffler, L. J. P., ed., Assessment of geothermal resources of the United States-1978: U.S. Geological Survey Circular 790, p. 18-85.

Capstick, D. O., and Hyndman, P. C., 1982a, Mineral resources of the Diablo RARE II Area (No. 5127), Santa Barbara County, California: U.S. Bureau of Mines MLA Open-File Report 55-82, 7 p.

$1982 \mathrm{~b}$, Mineral resources of the Little Pine RARE II Area (No. 5278), Santa Barbara County, California: U.S. Bureau of Mines MLA Open-File Report 53-82, 7 p.

Carman, M. F., Jr., 1964, Geology of the Lockwood V'alley area, Kern and Ventura Counties, California: California Division of Mines and Geology Special Report 81, 62 p.

Clark, W. B., 1970, Gold districts of California: California Division of Mines and Geology Bulletin 193, $186 \mathrm{p}$

Denton, D. K., Jr., 1982, Mineral resources of the Los $M^{-}$chos Hills RARE II Area (No. 5111), San Luis CDispo County, California: U.S. Bureau of Mines MLA OpenFile Report $3-82,8$ p.

Dibblee, T. W., 1973, Regional geologic map of San Ardreas and related faults in Carrizo Plain, Temblor, Cal :onte, and La Panza Ranges and vicinity, California: U.S. Geological Survey Miscellaneous Geologic Invertigations Map I-757, scale 1:125,000.

Dickinson, K. A., 1982, Epigenetic uranium deposits on Tertiary sedimentary rocks in Ventura County, California: a preliminary report: U.S. Geological Survey Open-File Report 82-818B, 26 p.

Dickinson, K. A., Frizzell, V. A., Jr., and Morrone, J. F., 1982, Geochemical data and airborne radioactivity from parts of west-central Ventura County, California: U.S. Geological Survey Open-File Report 82-818C, 10 p.

Eckel, E. B., Yates, R. G., and Granger, A. E., 1941, Gricksilver deposits in San Luis Obispo County and snuthwestern Monterey County, California: U.S. Geological Survey Bulletin 922-R, p. 515-580.

Fedewa, W. T., and Hovland, R. D., 1981, Phosphate rescurces of the upper Miocene phosphate deposits near New Cuyama, Santa Barbara County, California, in Roberts, A. E., and Vercoutere, T. L., Geology and petrolngy of the upper Miocene phosphate deposits near New Cuyama, Santa Barbara County, California: U.S. Geological Survey Open-File Report 81-1037, F. 68245.

Frederickson, N. O., 1985, Map of thermal alteration irdices in roadless areas and the Santa Lucia Wilderness in the Los Padres National Forest, southwestern California: U.S. Geological Survey Miscellaneous Field $\mathbf{S}^{\prime}$ 1dies Map MF-1655-F, scale $1: 250,000$ [in press].

Frizzell, V. A., Jr., and Claypool, G. E., 1983, Petroleum potential map of Mesozoic and Cenozoic rocks in roadless areas and the Santa Lucia Wilderness in the Los Padres National Forest, southwestern California: U.S. Geological Survey Miscellaneous Field $\mathrm{S}^{+}$.udies Map MF-1655-D, 18 p., scale 1:250,000.

Frizzell, V. A., Jr., and Hale, W. N., 1983, Sespe-Fr?zier, Diablo, Matilija, Dry Lakes, Sawmill-Bad'ands, Cuyama, Antimony, and Quatal Roadless areas, California, in Marsh, S. P., Kropschot, S. J.. and Dickinson, R. G., eds., Wilderness mineral poter tial- 
Asceinent of mineral-resource potential in U.S. Forest Service lands studied 1964-1984: U.S. Geological Survey Professional Paper 1300, v. 1, p. 363-366.

Frizzell, V. A. Jr., and Kuizon, Lucia, 1983a, Santa Lucia Wilderness, and Garcia Mountain, Black Mountain, La Panza, Machesna Mountain, Los Machos Hills, Big Rocks, and Stanley Mountain Roadless Areas, California, in Marsh, S. P., Kropschot, S. J., and Dickinson, R. G., eds., Wilderness mineral potentialAssessment of mineral-resource potential in U.S. Forest Service lands studied 1964-1984: U.S. Geological Survey Professional Paper 1300 , v. 1, p. 356-359.

1983b, Miranda Pine, Horseshoe Springs, Tepusquet Peak, La Brea, Spoor Canyon, Fox Mountain, and Little Pine Roadless Areas, California, in Marsh, S. P., Kropschot, S. J., and Dickinson, R. G., eds., Wilderness mineral potential-Assessment of mineral-resource potential in U.S. Forest Service lands studied 1964-1984: U.S. Geological Survey Professional Paper 1300, v. 1, p. 293-296.

Frizzell, V. A., Jr. and Vedder, J. G., 1985, Geologic map of roadless areas and the Santa Lucia Wilderness in the Los Padres National Forest, southwestern California: U.S. Geological Survey Miscellaneous Field Studies Map MF-1655-A, scale $1: 250,000$ [in press].

Gabby, P. N., 1981, Mineral resources of the Black Mountain RARE II Area (No. 5108), San Luis Obispo County, California: U.S. Bureau of Mines MLA Open-File Report 21-82, $12 \mathrm{p}$.

Godwin, L. H., and Stephens, E. V., 1979, Lands valuable for geothermal resources, southern California: U.S. Geological Survey, Conservation Division, Office of the Area Geologist, Pacific Region, scale 1:500,000.

Goldman, H. B., 1957, Antimony, in Wright, J. A., ed., Mineral commodities of California: California Division of Mines Bulletin 176, p. 35-44.

Gower, H. D., Vedder, J. G., Clifton, H. E., and Post E. V., 1966, Mineral resources of the San Rafael primitive area, California: U.S. Geological Survey Bulletin 1230-A, p. A1-A28.

Griscom, Andrew, 1985a, Aeromagnetic map of part of the Los Padres National Forest in the southem Coast and western Transverse Ranges, California: U.S. Geological Survey Miscellaneous Field Studies Map MF-1658A, scale $1: 250,000$ [in press].

$1985 \mathrm{~b}$, Bouguer gravity map of part of the Los Padres National Forest in the southern Coast and western Transverse Ranges, California: U.S. Geological Survey Miscellaneous Field Studies Map MF-1658-B, scale $1: 250,000$ in press]

Hale, W. N., Winters, R. A., Graham, D. E., and Neumann, T. R., 1983, Mineral investigation of the Sespe-Frazier RARE II Area (No. 5002), Ventura County, California: U.S. Bureau of Mines MLA Open-File Report, 78-83, $30 \mathrm{p}$.

Hart, E. W., 1978, Limestone, dolomite, and shell resources of the Coast Ranges province, California: California Division of Mines and Geology Bulletin 197, $103 \mathrm{p}$.

Horn, M. C., 1983, Mineral investigation of the mineral resources of the Horseshoe Spring RARE II Area (No. 5115), Santa Barbara County, California: U.S. Bureau of Mines MLA Open-File Report, 18-83, 9 p.

Howell, D. G., and Claypool, G. E., 1977, Reconnaissance petroleum potential of Mesozoic and Cenozoic Rocks, Coast Ranges, California, in Howell, D. G., Vedder, J. G., and MeDougall, Kristin, eds., Cretaceous geology of the California Coast Ranges, west of San Andreas fault: Pacific Section, Society of Economic Paleontologists and Mineralogist, Pacific Coast Paleogeography Field Guide 2, p. 85-90.

Jermain, G. D., and Ricker, S., 1949, Investigation of Antimony Peak, Kern County, California: U.S. Bureau of Mines Report of Investigations 4505, 5 p.

Kew, W. S. W., 1924, Geology and oil resources of a part of Los Angeles and Ventura Counties, California: U.S. Geological Survey Bulletin 753, 202 p.
Kuizon, Lucia, 1981, Mineral resources of the Cuyama RARE II Area (No. 5135), Santa Barbara and Ventura Counties, California: U.S. Bureau of Mines MLA Open-File Report 9-81, 11 p.

1982, Mineral investigation of the Antimony RARE II Area (No. 5136), Kern and Ventura Co'nties, California: U.S. Bureau of Mines MLA Open-File Report 71-82, 14 p.

1983a, Mineral investigation of the Big Rocks RARE II Area (No. 5112), San Luis Obispo County, California: U.S. Bureau of Mines MLA Open-File Report 12-83, 8 p.

$1983 \mathrm{~b}$, Mineral investigation of the Machesna Mnuntain RARE II Area (No. 5110), San Luis Obispo County, California: U.S. Bureau of Mines MLA Open-File Report 13-83, 11 p.

1983c, Mineral investigation of the Miranda Pine Rock RARE II Area (No. 5114), Santa Barbara County, California: U.S. Bureau of Mines MLA Open-File Report 19-83, 8 p.

1983d, Mineral investigation of the Stanley Mountain RARE II Area (No. 5113), San Luis Obispo County, California: U.S. Bureau of Mines MLA Open-File Report, 57-83, 13 p.

Kundert, C. J., 1957, Boron, in Wright, J. A., ed., Mlineral commodities of California: California Division of Mines Bulletin 176, p. 71-74.

Lambeth, R. H., 1982, Mineral resources of the Mratilija RARE II Area (No. (5129), Ventura and Santa Earbara Counties, California: U.S. Bureau of Mines MLA Open-File Report 64-82, 13 p.

Link, M. H., and Smith, P. R., 1982, Organic geochemistry of Ridge Basin, southern California, in Crowell, J. C., and Link, M. H., eds., Geologic history of Ridge Basin, southern California: Society of Economic Paleontologists and Mineralogists, Pacific Section, p. 191-197.

Lipton, D. A., 1981, Mineral resources of the Garcia Mcuntain RARE II Area (No. 5107), San Luis Obispo County, California: U.S. Bureau of Mines MLA Open-File Report 8-82, $9 \mathrm{p}$.

Longwill, W. D., 1982, Mineral resources of the Sa wmillBadlands RARE II Area (No. 5134), Ventura an' Kern Counties, California: U.S. Bureau of Mines MLA Open-File Report 51-82, $18 \mathrm{p}$.

McCulloch, R. B., and Neumann, T. R., 1982, Mineral investigation of the Fox Mountain RARE II Area (No. 5120), Santa Barbara County, California: U.S. Buræau of Mines MLA Open-File Report 128-82, 9 p.

McCulloh, T. H., Frizzell, V. A., Jr., Stewart, R. J., and Barnes, Ivan, 1981, Precipitation of laumontit? with quartz, thenardite, and gypsum at Sespe Hot S rings, western Transverse Ranges, California: Clay and Clay Minerals, v. 29, no. 5, p. 353-364.

Muffler, L. J. P., ed., 1979, Assessment of geothermal resources of the United States - 1978: U.S. Geo'ogical Survey Circular 790, 163 p.

Nagle, H. E., and Parker, E. S., 1971, Future oil and gas potential of onshore Ventura Basin, California: American Association of Petroleum Geologists Memoir 15, p. 254-296.

Pearson, R. C., Hayes, P. T., and Fillo, P. V., 1967, Mineral resources of the Ventana primitive area, Mcnterey County, California: U.S. Geological Survey Eulletin 1261-B, $42 \mathrm{p}$.

Sabine, Charles, and Esparza, L. E., 1981, Mineral resources of the Santa Lucia Wilderness, San Luis Obispo C Junty, California: U.S. Bureau of Mines MLA Open-File Report 16-82, 6 p.

Seiders, V. M., Esparza, L. E., Sabine, Charles, Spear, J. M., Stebbins, Scott, and Benham, J. R., 1983, Mineral resource potential map of part of the Ventana T'ilderness and the Black Butte, Bear Mountain, and Bear Canyon Roadless Areas, Monterey County, California: U.S. Geological Survey Miscellaneour Field Studies Map MF-1559-A, scale 1:50,000.

Sheldon, R. P., 1963, Physical stratigraphy and mineral resources of Permian rocks in western Wyoming: U.S. Geological Survey Professional Paper 313-B, 273 p. 
Smith, D. B., Frizzell, V. A., Jr., Adrian, B. M., Vaughn, R. B., and MeDougal, C. M., 1985, Geochemical map of roadless areas and the Santa Lucia Wilderness Area in the Los Padres National Forest, southwestern California: U.S. Geological Survey Miscellaneous Field Studies Map MF-1655-E, scale 1:250,000 [in press].

Taylor, J. C., 1976, Geologic appraisal of the petroleum potential of offshore southem California: the Borderland compared to onshore coastal basins: U.S. Geological Survey Circular 730, $43 \mathrm{p}$.

Thor, D. R., 1978, Depositional environments and paleogeographic setting of the Santa Margarita Formation, Ventura County, California, in Fritsche, A. F., ed., Depositional environments of Tertiary rocks along Sespe Creek, Ventura County, California: Society of Economic Paleontologists and Mineralogists, Pacific Section, Pacific Coast Paleogeography Field Guide 3, p. 42-59.

Troxel, B. W., and Morton, P. K., 1962, Mines and mineral resources of Kem County, California: California Division of Mines and Geology, County Report 1, 370 p.

Tucker, W. B., and Sampson, R. J., 1932, Ventura County, in Mining in California: California Division of Mines Report of the State Mineralogist; 28, p. 247-277.

U.S. Bureau of Mines, 1985, Mines and prospects map of roadless areas and the Santa Lucia Wilderness in the Los Padres National Forest, southwestern California: U.S. Geological Survey Miscellaneous Field Studies Map MF-1655-C, scale 1:250,000 [in press].
U.S. Bureau of Mines, 1965, Mercury potential of the Un'ted States: Bureau of Mines Information Circular IC 8252 , $376 \mathrm{p}$.

Vedder, J. G., Dibblee, T. W., Jr., and Brown, R. D., Jr., 1973, Geologic map of the upper Mono Creek-Pine Mountain area, California: U.S. Geological Survey Miscellansous Geologic Investigations Map I-752, scale 1:48,000.

Ver Planck, W. E., 1957, Boron, in Wright, L. A., ed., Minsral commodities of California: California Division of Mines Bulletin 176, p. 87-95.

Weber, F. H., Jr., Cleveland, G. B., Kahle, J. E., Kiessling, E. F., Miller, R. V., Mills, M. F., and Morton, D. M., 1973, Geology and mineral resources study of south arn Ventura County, California: California Division of Mines and Geology Preliminary Report 14, 102 p.

White, W. W., III, 1982a, Mineral investigation of the Dry Lakes RARE II Area (No. 5131), Ventura County, California: U.S. Bureau of Mines MLA Open-File Report 84-82, 17 p.

$1982 \mathrm{~b}$, Mineral investigation of the Quatal RARE II A rea (No. 5268), Ventura County, California: U.S. Burea's of Mines MLA Open-File Report 68-82, 15 p.

Yeats, R. S., 1983, Large-scale quaternary detachment: in Ventura Basin, southern California: Journal of Ceophysical Research, vol. 88, no. B1, p. 569-583. 


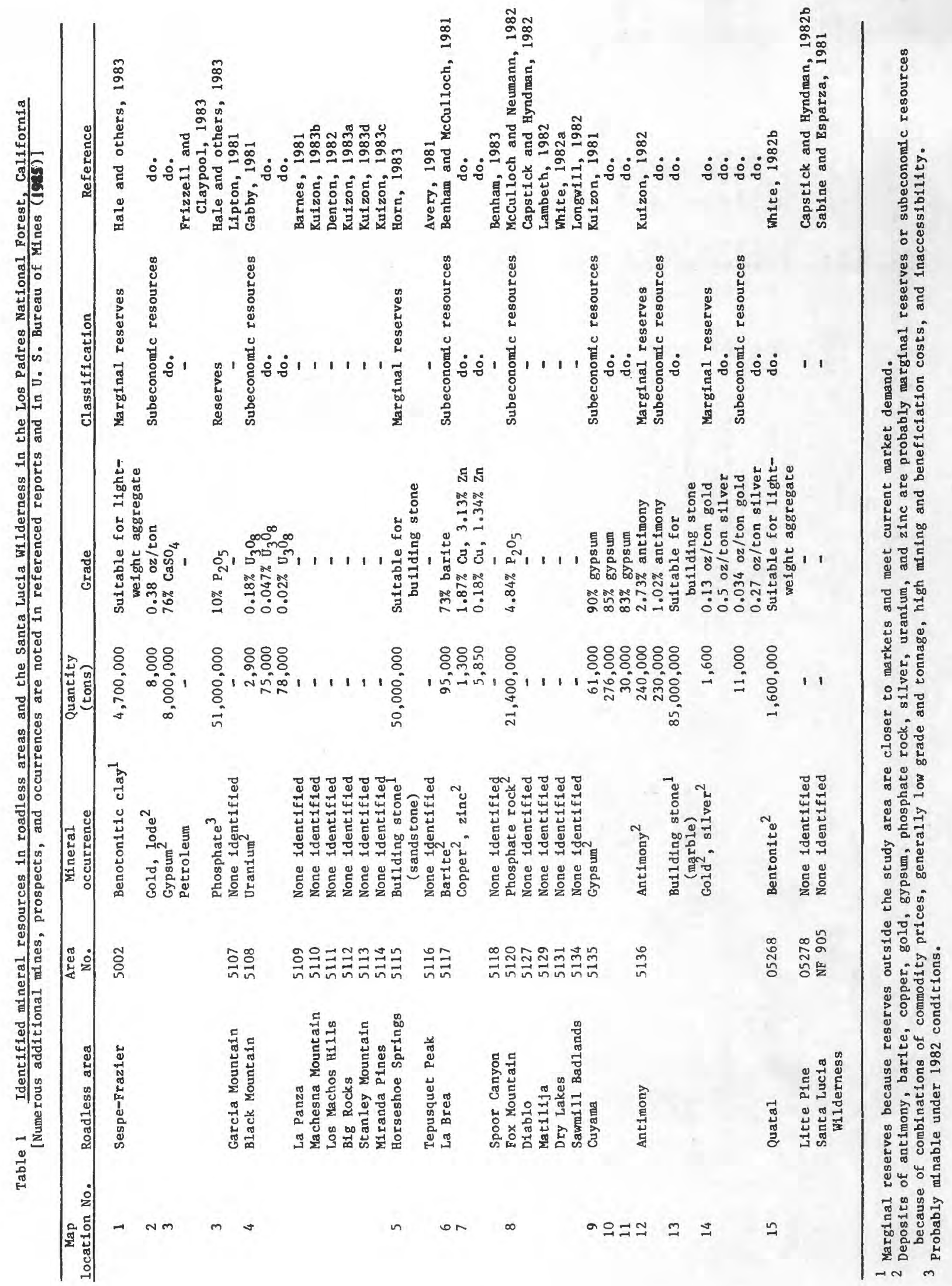




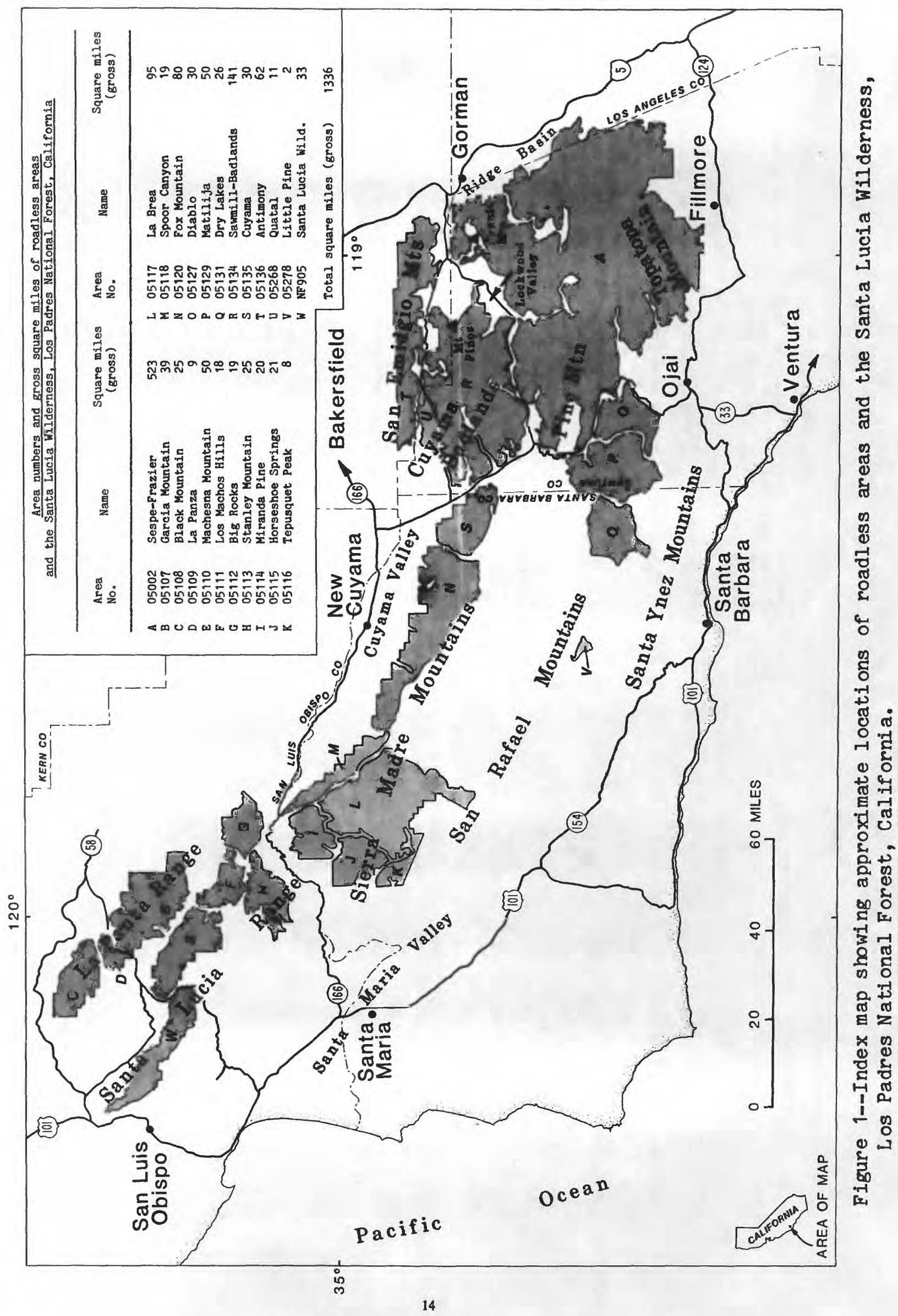




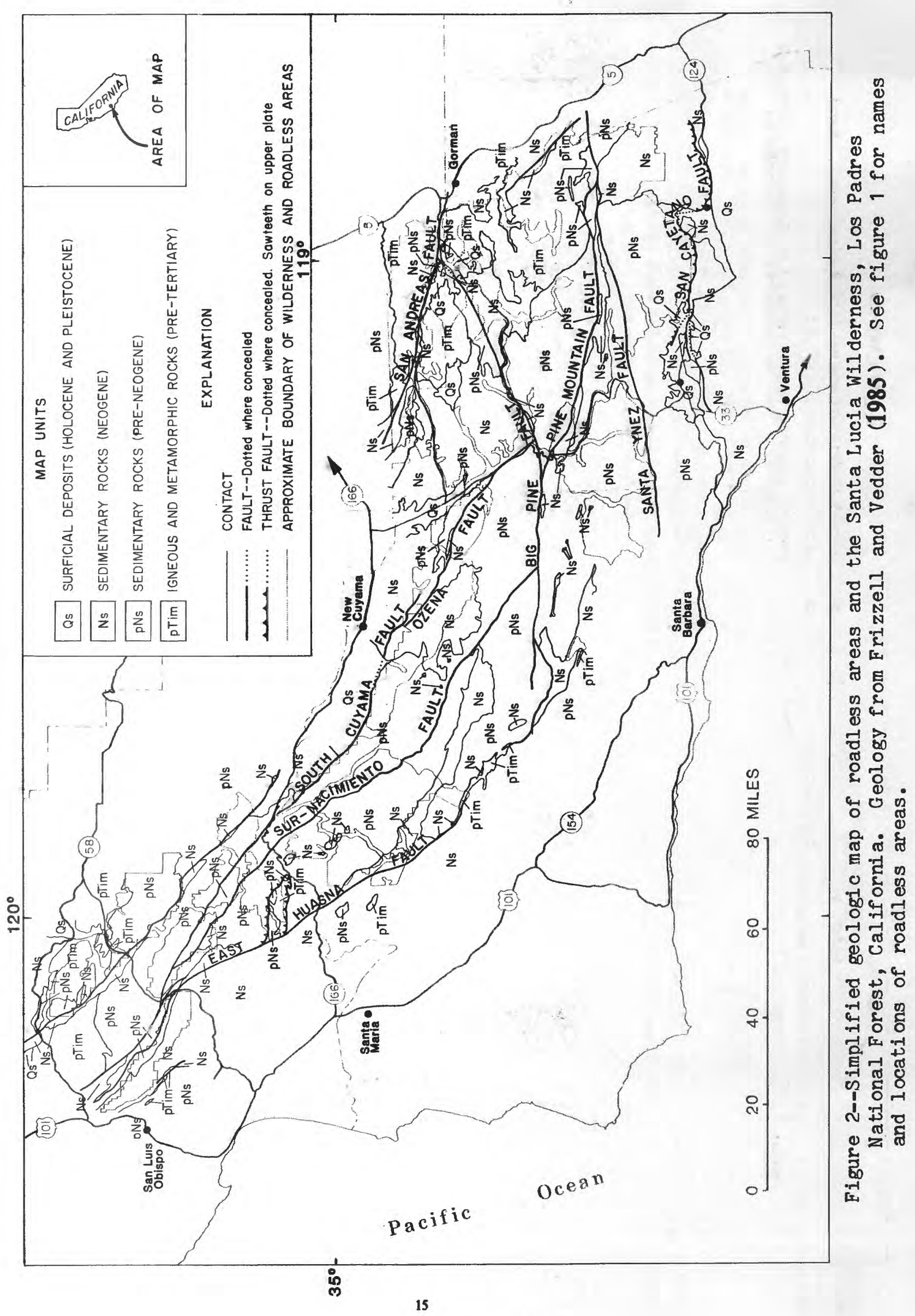




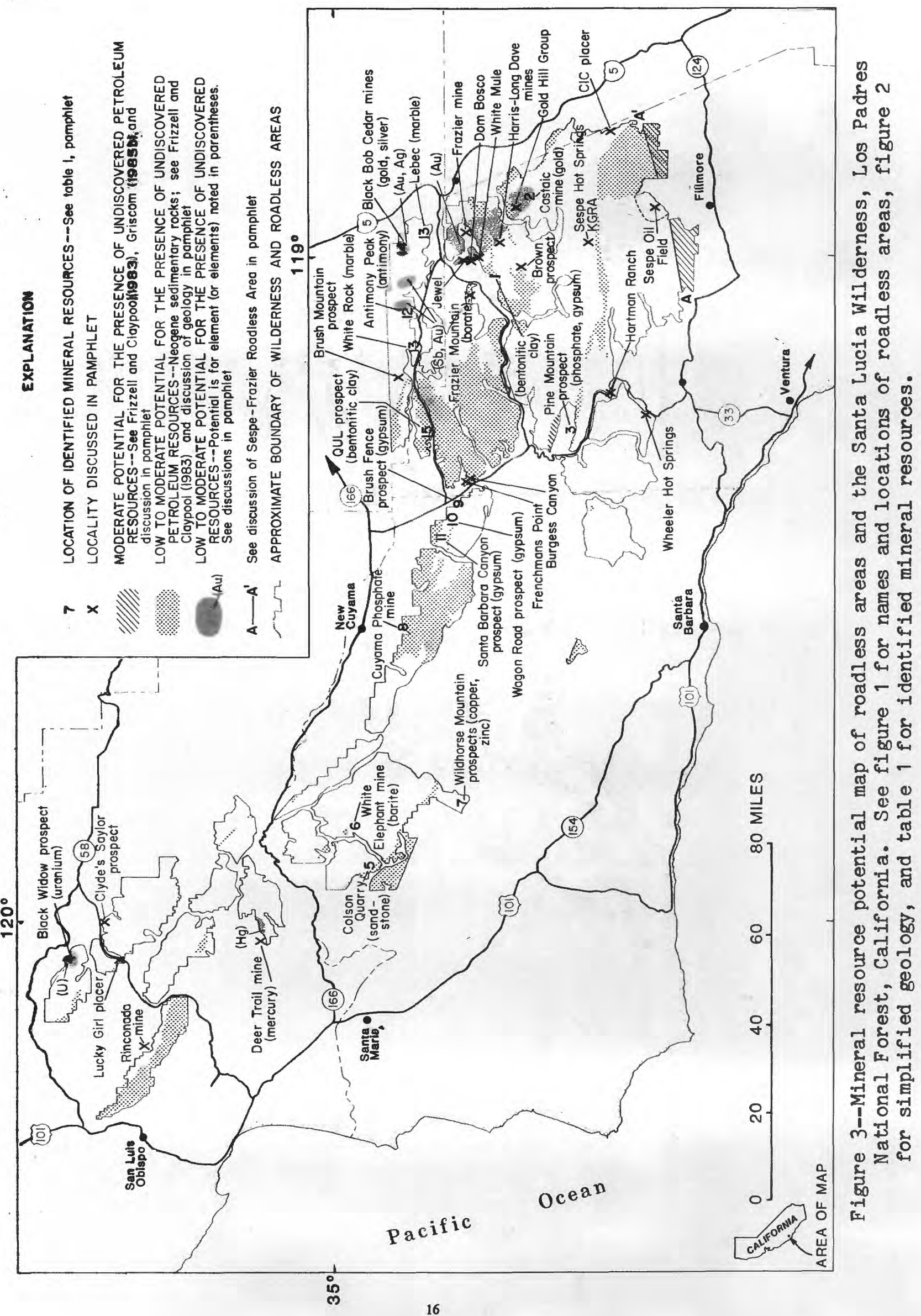

